\title{
ADAPTABILITAS PENORMAAN FIKIH WAKAF KE DALAM LEGISLASI NASIONAL
}

\author{
Yulkarnain Harahab* \\ Departemen Hukum Islam, Fakultas Hukum, Universitas Gadjah Mada, \\ Jl. Sosio Yustisia Nomor 1, Bulaksumur, Yogyakarta 55281
}

\begin{abstract}
This research conducted with the aim to find out and analyze the adaptation of the formulation of fiqh waqf in national legislation, knowing, and analyzing the principles that can be drawn from the formalization of fiqh waqf into national legislation. This research is a normative juridical research that is descriptive in nature. Data collection carry out by studying documents of primary and secondary legal materials. The collected data is then analyzed qualitatively. Based on the research conducted, the following conclusions are obtained: first, the adaptability of the waqf regulation in the national legislation was shown by several things, first: the elements of waqf (waqif, nazhir, endowment property, endowment pledge, endowment allotment, and time period) waqf), management and development of waqf property, registration and reporting of waqf property, also changes in the designation and status of waqf property; second, the principles that can be drawn from the regulation of figh waqf into national legislation: the principle of benefit, the principle of legal certainty, the principle of professionalism, and the principle of accountability. Keywords: adaptability, fiqh, waqf, statutory regulations.
\end{abstract}

\section{Intisari}

Penelitian ini dilakukan dengan tujuan, pertama, untuk mengetahui dan menganalisis adaptabilitas penormaan fikih wakaf ke dalam legislasi nasional; kedua, mengetahui dan menganalisis prinsip-prinsip yang dapat ditarik dari penormaan fikih wakaf ke dalam legislasi nasional. Penelitian ini merupakan penelitian yuridis normatif yang bersifat deskriptif. Pengumpulan data dilakukan dengan studi dokumen terhadap bahan hukum primer dan bahan hukum sekunder. Data yang telah terkumpul selanjutnya dianalisis secara kualitatif. Berdasarkan penelitian yang telah dilakukan, diperoleh kesimpulan sebagai berikut: pertama, adaptabilitas pengaturan fikih wakaf ke dalam legislasi nasional ditunjukkan dalam beberapa hal, yaitu: unsur-unsur wakaf (wakif, nazhir, harta benda wakaf, ikrar wakaf, peruntukan wakaf, dan jangka waktu wakaf), pengelolaan dan pengembangan harta benda wakaf, pendaftaran dan pelaporan harta benda wakaf, serta perubahan peruntukan dan status harta benda wakaf; kedua, prinsip-prinsip yang dapat ditarik dari pengaturan fikih wakaf ke dalam legislasi nasional, yakni: prinsip kemaslahatan, prinsip kepastian hukum, prinsip profesionalitas, dan prinsip akuntabilitas.

Kata kunci: adaptabilitas, fikih, wakaf, peraturan perundang-undangan.

\section{Pokok Muatan}

A. Latar Belakang Masalah

B. Metode Penelitian

C. Hasil Penelitian dan Pembahasan

1. Adaptabilitas Pengaturan Wakaf dari Ajaran Fikih ke Dalam Peraturan PerUndang-Undang an di Indonesia.

2. Prinsip-prinsip yang Dapat Ditarik dari Pengaturan Fikih Wakaf ke Dalam Peraturan PerUndang-Undang an di Indonesia.

D. Kesimpulan

Alamat korespondensi: yulkarnain.harahap@mail.ugm.ac.id. 


\section{A. Latar Belakang Masalah}

Wakaf adalah salah satu ajaran Islam yang tidak hanya berdimensi spiritual, melainkan juga berdimensi sosial. Wakaf sebagai salah satu amal karitatif dalam Islam memegang peranan penting dalam menunjang kegiatan ibadah ataupun kegiatan sosial dalam masyarakat. Pelaksanaan ajaran wakaf didasarkan keyakinan bahwa wakaf merupakan ibadah yang akan mengalir terus pahalanya kepada orang yang berwakaf sekalipun yang bersangkutan sudah meninggal dunia ${ }^{1}$.

Semenjak kedatangan Islam ke bumi Nusantara beberapa abad yang silam, ajaran wakaf juga menyebar di kalangan umat Islam. Wakaf sudah lama dipraktikkan umat Islam di Indonesia dalam kehidupan sehari-hari. Masjid, makam, dan pondok pesantren adalah beberapa contoh bangunan atau sarana yang didirikan di atas tanah wakaf. Harta yang diwakafkan pada masa lalu sebagian besar berupa tanah yang diperuntukkan bagi keperluan peribadatan ${ }^{2}$. Proses perwakafan dilakukan secara sederhana, yaitu melalui ikrar (pernyataan) secara lisan oleh yang berwakaf di hadapan ulama/ kyai atau kepada warga masyarakat pada acara keagamaan.

Salah satu faktor yang mewarnai corak dan perkembangan wakaf di era modern adalah adanya campur tangan negara dalam kebijakan wakaf melalui seperangkat hukum positif. Dalam proses perumusan kebijakan tersebut, ditentukan oleh bagaimana penguasa melihat potensi maupun organsisasi wakaf, baik dalam kerangka kepentingannya, maupun kepentingan umat Islam pada umumnya. Dalam hal ini, kepentingan kesejahteraan sosial sangat kuat mempengaruhi proses regulasi di bidang perwakafan.
Saat ini, persoalan perwakafan di Indonesia diatur dalam Undang-Undang Nomor 41 Tahun 2004 tentang Wakaf dan Peraturan Pemerintah Nomor 42 tahun 2006 tentang Pelaksanaan UndangUndang Nomor 41 Tahun 2004 tentang Wakaf, Peraturan Pemerintah Nomor 25 ahun 2018 tentang Perubahan Atas Peraturan Pemerintah Nomor 42 Tahun 2006 tentang Pelaksanaan Undang-Undang Nomor 41 Tahun 2004 tentang Wakaf serta beberapa peraturan yang dikeluarkan Menteri Agama dan Badan Wakaf Indonesia (BWI). Dikeluarkannya Undang-undang Wakaf tersebut didasarkan pada pertimbangan, pertama, lembaga wakaf sebagai pranata keagamaan yang memiliki potensi dan manfaat ekonomi perlu dikelola secara efektif dan efisien untuk kepentingan ibadah dan untuk memajukan kesejahteraan umum, kedua, wakaf merupakan perbuatan hukum yang telah lama hidup dan dilaksanakan dalam masyarakat, namun pengaturannya belum lengkap serta masih tersebar dalam berbagai peraturan perundang-undangan ${ }^{3}$.

Ajaran wakaf merupakan salah satu ajaran Islam yang sebagian besar pengaturannya dalam Al-Qur'an dan Sunah tidak bersifat pasti (qath'i) atau terperinci, sehingga ketentuan wakaf sebagian besar merupakan wilayah ijtihadiyah para mujtahid. Oleh karena ajaran wakaf bersifat ijtihadi dan bukan ajaran yang bersifat ta'abudi maka ketentuan wakaf bersifat lebih fleksibel dari pada ketentuan ibadah lainnya. Berdasarkan hal tersebut, dapat dipahami bahwa ajaran wakaf dalam fikih lebih banyak bersifat ijtihadiyah ${ }^{4}$.

Peraturan perundang-perundangan yang beberapa di antaranya merupakan positivisasi bidang hukum Islam tertentu, seperti bidang wakaf, tidak lepas dari ijtihad para perumusnya. Ketentuan

\footnotetext{
Dalam Hadits Riwayat Muslim disebutkan bahwa dari Abu Hurairah radhiyallahu 'anhu, ia berkata bahwa Rasulullah shallallahu 'alaihi wa sallam bersabda, "Jika seseorang meninggal dunia, maka terputuslah amalnya kecuali tiga perkara (yaitu): sedekah jariyah, ilmu yang dimanfaatkan, atau do'a anak yang shalih” (HR. Muslim no. 1631). Yang dimaksud sedekah jariyah adalah amalan yang terus bersambung manfaatnya, seperti wakaf.

Departemen Agama RI, 2003, Perkembangan Pengelolaan Wakaf di Indonesia, Proyek Peningkatan Zakat dan Wakaf Direktorat Jenderal Bimbingan Masyarakat Islam dan Penyelenggaraan Haji, Jakarta, hlm. 1-2.

Undang-Undang Nomor 41 Tahun 2004 tentang Wakaf.

Fikih adalah hasil interpretasi atau pemahaman fuqaha terhadap ketentuan syariat yang ada dalam Al-Qur'an dan As-Sunnah. Fikih yang diacu dalam tulisan ini adalah Fikih yang ditulis Sulaiman Rasyid, Sayyid Sabiq, Wahbah al-Zuhaili, dan Al-Kabisi.
} 
dalam peraturan perundang-undangan tersebut sebagian diambil dari ajaran fikih dengan beberapa penyesuaian melalui ijtihad. Dalam Islam, ijtihad merupakan suatu hal yang tidak asing untuk menyelesaikan suatu permasalahan yang tidak ada atau tidak jelas pengaturannya dalam Al-Qur'an dan Sunnah. Dalam berijtihad, kemaslahatan merupakan orientasi yang menjadi acuan para mujtahid ${ }^{5}$.

Peraturan perundang-undangan wakaf di Indonesia mengatur hal-hal yang terkait wakaf, baik yang menyangkut aspek substantif maupun administratif. Hal-hal yang menyangkut substansi wakaf meliputi unsur-unsur dan syarat-syarat wakaf, serta perubahan status dan peruntukan harta benda wakaf, sedangkan hal-hal yang menyangkut administrasi wakaf meliputi pendaftaran dan pengumuman harta benda wakaf, pengelolaan dan pengembangan harta benda wakaf, Kelembagaan dan Tugas Badan Wakaf Indonesia, serta pembinaan dan pengawasan terhadap penyelenggaraan wakaf.

Beberapa pembaharuan ketentuan wakaf yang termuat dalam peraturan perundang-undangan meliputi perluasan pihak-pihak yang bisa menjadi wakif dan nadzir, perluasan jenis harta yang bisa diwakafkan, jangka waktu wakaf yang tidak harus selamanya, perubahan status harta benda wakaf dengan syarat dan prosedur yang jelas, serta pengelolaan dan pengembangan harta benda wakaf yang diatur terperinci. Ketentuan-ketentuan tersebut berbeda dengan apa yang diajarkan dalam fikih. Kenyataan tersebut menarik penulis untuk meneliti lebih lanjut tentang sejauh mana adaptabilitas penormaan fikih wakaf ke dalam legislasi nasional.

Berdasarkan uraian di atas, permasalahan yang diangkat Penulis dalam penelitian ini adalah pertama, bagaimana adaptabilitas penormaan fikih wakaf ke dalam legislasi nasional. Kedua, prinsipprinsip apakah yang dapat ditarik dari penormaan fikih wakaf ke dalam legislasi nasional tersebut.

\section{B. Metode Penelitian}

Penelitian yang dilakukan ini merupakan penelitian hukum normatif, artinya penelitian yang lebih mengutamakan pada kajian data sekunder, yang berupa peraturan perundang-undangan, tulisan pada jurnal, maupun buku-buku yang terkait dengan topik penelitian. Kajian terhadap peraturan perundang-undangan dan literatur ini untuk menjawab rumusan masalah yang lebih pada aras normatif, yaitu adaptabilitas penormaan fikih ke dalam legislasi nasional dan prinsip-prinsip yang dapat ditarik dari penormaan fikih wakaf ke dalam legislasi nasional tersebut. Dilihat dari sifatnya, penelitian yang dilakukan penulis adalah penelitian deskriptif, artinya penelitian yang bertujuan untuk mendeskripsikan atau menggambarkan suatu persoalan dan analisis terhadap persoalan tersebut.

Data dalam penelitian ini berupa data sekunder yang terdiri dari bahan hukum primer dan bahan hukum sekunder. Bahan hukum primer tersebut meliputi Undang-Undang Nomor 41 Tahun 2004 tentang Wakaf, Peraturan Pemerintah Nomor 42 Tahun 2006 tentang Pelaksanaan UndangUndang Nomor 41 Tahun 2004 tentang Wakaf, Peraturan Pemerintah Nomor 25 ahun 2018 tentang Perubahan Atas Peraturan Pemerintah Nomor 42 Tahun 2006 tentang Pelaksanaan Undang-Undang Nomor 41 Tahun 2004 tentang Wakaf, Peraturan Menteri Agama Nomor 73 Tahun 2013 tentang Tata Cara Perwakafan Benda Tidak Bergerak dan Benda Bergerak Selain Uang, Peraturan Menteri Agama Nomor 4 Tahun 2009 tentang Administrasi Pendaftaran Wakaf Uang, Peraturan Badan Wakaf Indonesia Nomor 1 Tahun 2008 tentang Prosedur Penyusunan Rekomendasi terhadap Permohonan Penukaran/ Perubahan Status Harta Benda Wakaf, Peraturan Badan Wakaf Indonesia Nomor 3 Tahun 2008 tentang Tata Cara Pendaftaran dan Penggantian Nazhir Harta Benda Wakaf Tidak Bergerak Berupa Tanah, dan Peraturan Badan Wakaf Indonesia Nomor 1 Tahun 2009 tentang Pedoman Pengelolaan dan Pengembangan Harta 
Benda Wakaf Berupa Uang. Adapun bahan hukum sekunder meliputi buku-buku, artikel jurnal, dan hasil penelitian. Pengumpulan data tersebut dilakukan dengan studi dokumen.

Data yang telah dikumpulkan selanjutnya dianalisis secara kualitatif. Dalam melakukan analisis data ini, ketentuan yang ada dalam ajaran fikih wakaf disandingkan dengan ketentuan yang ada dalam perundang-undangan wakaf, selanjutnya ditelaah persamaan dan perbedaannya. Hal ini dilakukan untuk mengetahui bagaimana adaptabilitas penormaan fikih wakaf ke dalam lgislasi nasional. Dalam penelitian ini ada tiga alur kegiatan yang dilakukan, yaitu reduksi data, penyajian data, dan penarikan kesimpulan ${ }^{6}$. Penarikan kesimpulan dilakukan secara deduktif dan induktif untuk menjawab rumusan masalah yang ada.

\section{Hasil Penelitian dan Pembahasan}

1. Adaptabilitas Pengaturan Wakaf dari Ajaran Fikih ke Dalam Peraturan PerUndang-Undang an di Indonesia

Untuk sahnya wakaf, menurut Sulaiman Rasjid $^{7}$ dan Wahbah Zuhaili ${ }^{8}$ yang mengacu pada fikih madzab Syafi'i, harus terpenuhi rukunrukunnya yang meliputi empat hal, yaitu:
a. $\quad$ Pihak yang berwakaf (wakif);
b. $\quad$ Barang yang diwakafkan (mauquf);
c. Sasaran atau Pihak yang menerima wakaf (mauquf 'alaih); dan
d. Pernyataan/ikrar wakaf (shighat).

Masing-masing rukun wakaf di atas harus memenuhi syarat-syarat tertentu, yaitu sebagai berikut:
a. Pihak yang berwakaf (waqif)
Syarat bagi pihak yang mewakafkan
hartanya menurut Sulaiman Rasjid adalah

berhak berbuat kebaikan, sekalipun ia bukan Islam, dan Kehendak sendiri, sehingga wakaf tidak sah jika dipaksa. ${ }^{9}$ Adapun menurut Muhammad Abid Abdullah Al-Kabisi ${ }^{10}$, syarat wakif adalah baligh dan berakal. Oleh karena itu wakaf yang dilakukan oleh orang yang tidak sehat akal (gila), orang pingsan, orang tidur dan orang mabuk, anak di bawah umur, orang yang lemah ingatan karena faktor usia (pikun), dan orang yang berada dalam kekuasaan orang lain (dalam pengampuan) adalah tidak sah.

Adapun menurut Wahbah Zuhaili ${ }^{11}$, persyaratan yang harus dipenuhi waqif meliputi perkataannya dapat dipertanggungjawabkan, baik seorang muslim atau kafir. Berdasarkan hal ini, maka waqif harus sudah baligh dan berakal sempurna, sehingga wakaf yang dilakukan anak-anak dan orang gila adalah tidak sah. Sebaliknya wakaf yang dilakukan orang kafir adalah sah walaupun berwakaf pada masjid dan meskipun dia tidak meyakini bahwa wakaf adalah sarana mendekatkan diri kepada Allah sesuai dengan keyakinan muslim, Memiliki kemampuan berderma. Berdasarkan hal ini, wakaf yang dilakukan oleh orang yang berstatus di bawah pengampuan karena menghamburhamburkan harta atau karena pailit adalah tidak sah.Waqif melakukannya atas dasar inisiatif sendiri, sehingga hukum wakaf dari orang yang dipaksa melakukan wakaf adalah tidak sah.

\section{b. Barang yang diwakafkan (mauquf) \\ Syarat yang harus dipenuhi untuk} barang atau harta yang diwakafkan adalah a) kekal zatnya, artinya bila manfaatnya

Matthew B. Miles dan A. Michael Huberman,1992, Qualitative Data Analysis (Analisis Data Kualitatif), terj. Tjetjep Rohendi Rohidi, UIPress, Jakarta, hlm. 16-19.

Sulaiman Rasjid, 1997, Fiqh Islam, Sinar Baru Algensindo, Bandung, hlm. 341-342

Wahbah Zuhaili, 2010, Fiqih Imam Syafi'i, Mengupas Masalah Fiqhiyah Berdasarkan Al-Qur'an dan Hadits, Jilid 2, Al-Mahira, Jakarta, hlm. 343.

Sulaiman Rasyid, Op. cit., hlm. 341.

10 Al-Kabisi, Muhammad Abid Abdullah, 2004, Hukum Wakaf, Kajian Kontemporer Pertama dan Terlengkap tentang Fungsi dan Pengelolaan Wakaf serta Penyelesaian Atas Sengketa Wakaf, terj. Ahrul Sani Fathurraman, Dompet Dhuafa Republika dan IIMaN, Jakarta, hlm. 7.

11 Wahbah Zuhaili, Op.cit., hlm. 346-347. 
diambil, zat barang itu tidak rusak; dan b) Kepunyaan yang mewakafkan, walaupun musya' (bercampur dan tidak dapat dipisahkan dari yang lain) ${ }^{12}$.

Menurut Sayyid Sabiq ${ }^{13}$, harta atau benda yang sah diwakafkan meliputi tanah, perabot yang bisa dipindahkan, mushaf, kitab, senjata dan binatang. Selain itu sah pula untuk mewakafkan apa-apa yang boleh diperjualbelikan dan boleh dimanfaatkan dan tetap utuhnya barang. Adapun yang tidak sah untuk diwakafkan adalah segala sesuatu yang rusak dengan dimanfaatkannya, seperti uang, lilin, makanan, minuman, dan apa yang cepat rusak seperti wangi-wangian dan tumbuh-tumbuhan aromatik. Tidak boleh juga untuk diwakafkan apa yang tidak boleh diperjualbelikan seperti barang tanggungan (borg), anjing, babi, dan binatang-binatang buas lainnya yang tidak bisa dijadikan sebagai hewan pelacak buruan

Menurut Al-Kabisi ${ }^{14}$, suatu benda dapat diwakafkan jika obyek wakaf tersebut merupakan sesuatu yang bisa dimiliki/ dikuasasidandidayagunakan, dapatdiketahui, dan sepenuhnya merupakan milik orang yang berwakaf. Adapun menurut Zuhaili ${ }^{15}$, syarat-syarat untuk barang yang diwakafkan adalah Mauquf harus berupa barang yang telah tersedia yang dapat dimanfaatkan serta wujudnya tetap utuh selama-lamanya. Berdasarkan hal tersebut, mewakafkan barang tak bergerak seperti tanah, rumah dan barang bergerak seperti kain, kitab, hewan, perkakas rumah tangga, dan jenis senjata tertentu adalah sah. Sebaliknya mewakafkan makanan, wewangian, dan hal-hal yang sejenis keduanya, yakni barang yang tidak dapat dimanfaatkan untuk selamanya adalah tidak sah, Mauquf harus berupa barang yang sudah berwujud (bukan sesuatu yang belum ada), Mauquf harus berupa kekayaan yang berharga, mubah, sudah diketahui, serta dapat dimiliki secara penuh. Berdasarkan hal tersebut maka mewakafkan sesuatu yang bukan kekayaan (seperti kulit bangkai), barang tidak berharga di mata syara' (seperti khamr), barang yang tidak dapat dijadikan hak milik (seperti anjing), barang yang dilarang digunakan oleh syariat (seperti alat hiburan), barang yang belum diketahui, barang yang belum ditentukan, dan juga barang dalam bentuk tanggungan adalah tidak sah atau batal.

Selanjutnya menurut pendapat yang shahih, wakaf berupa barang berharga (emas dan perak) atau uang dinar dan dirham tidak diperbolehkan karena barang berharga semacam itu tidak boleh disewakan. ${ }^{16}$ Dalam Al-Qur'an dan hadits, juga tidak ada satu ayat atau teks hadits yang secara eksplisit menyebutkan wakaf uang.

c. Tempat berwakaf/sasaran wakaf/pihak yang berhak menerima hasil wakaf (mauquf'alaih)

Terkait dengan sasaran wakaf (mauquf 'alaih), Sayyid Sabiq ${ }^{17}$ menyatakan bahwa tidak sah wakaf kecuali kepada orang yang dikenal, seperti anak, kerabat, dan orang tertentu; atau untuk kebaikan, seperti membangun masjid, jembatan, pengadaan kitab-kitab fiqih dan Al-Qur'an. Apabila wakaf ditujukan kepada orang yang tidak tertentu, seperti kepada seorang lelaki dan seorang perempuan, atau untuk maksiat, seperti wakaf untuk gereja dan biara, maka yang demikian ini tidak sah. Namun wakaf terhadap ahli dzimmah, seperti orang-orang

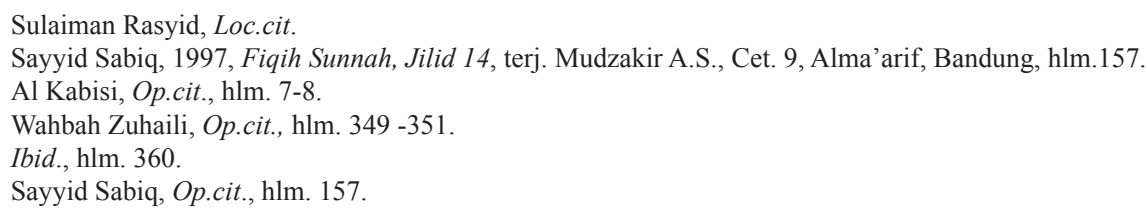


Nasrani, hal ini diperbolehkan sebagaimana diperbolehkannya sedekah kepada mereka. Hal ini didasarkan pada riwayat bahwa Shafiyah binti Huyyai (isteri Nabi SAW) pernah mewakafkan kepada saudaranya yang Yahudi. Apabila wakif mewakafkan dengan wakaf muthlak dan tidak menentukan bagi siapa wakaf itu, seperti ia mengatakan "Rumah untuk wakaf", maka wakaf seperti ini menurut pendapat yang kuat dari madzab Syaf'i tidak sah karena tidak adanya penjelasan siapa yang diberi wakaf. ${ }^{18}$

Menurut Al-Kabisi ${ }^{19}$, syarat untuk sasaran wakaf adalah: a) Sasaran wakaf tersebut merupakan bentuk kebajikan; b) Sasaran tersebut tidak boleh terputus (langgeng); c) Barang wakaf tidak boleh dikembalikan pada orang yang berwakaf; d) Obyek wakaf harus bisa dimiliki dan dirasakan manfaatnya. Adapun menurut Zuhaili ${ }^{20}$, sasaran pengalokasian wakaf (mauquf 'alaih) bisa berupa seseorang yang telah ditentukan, dan bisa juga berupa jalan kebaikan, misalnya wakaf untuk berjihad di jalan Allah atau sebuah masjid. Apabila wakaf dialokasikan pada sesuatu atau seseorang yang telah ditentukan, maka syaratnya adalah sesuatu atau seseorang itu harus ada dan dapat diketahui, sehingga wakaf pada sesuatu yang belum ada, seperti janin dalam kandungan atau seseorang yang akan dilahirkan, dan wakaf pada perkara yang belum diketahui adalah tidak sah karena pengalokasian hasil wakaf sulit dilakukan, wakaf tidak boleh diserahkan pada orang kafir harbi, murtad, atau pada diri waqif sendiri. Hal tersebut dikarenakan kafir harbi ialah musuh yang bisa memanfaatkan barang wakaf untuk memperkuat posisinya melawan kaum muslimin, sementara orang murtad dihadapkan pada hukuman mati jika dia tetap dalam kondisi murtad dan enggan bertaubat, sehingga dia tidak dapat memiliki wakaf untuk selamanya, padahal wakaf merupakan sedekah jariyah. Penyerahan wakaf untuk dirinya sendiri dianggap sulit, sebab tidak mungkin seseorang menyerahkan hak miliknya pada dirinya sendiri, karena tanpa diserahkan pun hak milik itu sudah ada dalam genggamannya.

Adapun wakaf untuk jalan kebaikan, syaratnya adalah harus berupa arah kebajikan, misalnya masjid, madrasah, orang fakir dan kerabat dekat. Berdasarkan hal ini maka hukum seseorang yang mewakafkan pada sesuatu yang tidak mengandung nilai ibadah, seperti tempat peribadatan orang Kristen dan Yahudi, kitab Taurat dan Injil, dan pada seorang perampok atau orang murtad adalah tidak sah, karena wakaf bertujuan mendekatkan diri pada Allah, sementara perkara yang telah disebutkan tersebut menolong terwujudnya kemaksiatan.

Arah kebajikan tersebut tidak terhenti di awal atau di akhir. Berdasarkan hal tersebut apabila seseorang mewakafkan barang kepada anaknya, padahal dia tdak mempunyai anak, maka hukum wakaf semacam ini adalah batal karena anak yang belum lahir (belum ada) tidak mempunyai kekuasaan memiliki. Oleh karena itu, wakaf pada orang semacam ini tidak ada gunanya sama sekali. Selanjutnya menurut pendapat azhar, apabila waqif hanya berkata "saya mewakafkan", maka wakaf semacam ini juga batal karena tidak menyebutkan tempat pengalokasian wakaf. Namun apabila waqif mewakafkan pada si Zaid, tanpa menuturkan setelahnya diberikan pada fulan, wakaf semacam ini hukumnya sah. Setelah si Zaid, 
wakaf diserahkan pada orang fakir yang mempunyai hubungan kekerabatan dengan waqif ${ }^{21}$.

Berdasarkan hal di atas wakaf tidak boleh dialokasikan untuk perbuatan terlarang, sehingga hukum wakaf untuk membeli alat merampok adalah haram ${ }^{22}$. Demikian juga memberi wakaf pada tempat peribadatan orang Kristen atau Yahudi, kitab Taurat dan Injil, adalah tidak diperbolehkan sebab semua itu barang yang diharamkan untuk digunakan ${ }^{23}$.

d. Lafaz/Pernyataan Wakaf (Shighat).

Menurut Sayyid Sabiq ${ }^{24}$, wakaf itu sah dan terjadi melalui salah satu dari dua perkara, yaitu, perbuatan, yang menunjukkan padanya, seperti apabila seseorang membangun masjid dan dikumandangkan adzan untuk shalat di dalamnya, ucapan, baik secara sharih (tegas) maupun kinayah (tersembunyi). Ucapan yang sharih misalnya "aku wakafkan", "aku hentikan pemanfaatannya", "aku jadikan untuk sabilillah". Adapun ucapan yang kinayah, misalnya "aku sedekahkan", dengan niat mewakafkannya

Terkait dengan pernyataan wakaf, ada beberapa syarat yang harus dipenuhi, yaitu selama-lamanya, berarti tidak dibatasi dengan waktu, tunai dan tidak ada khiyar syarat, hal ini dikarenakan maksud wakaf adalah memindahkan hak milik pada waktu itu, hendaklah jelas kepada siapa diwakafkan, jika tidak jelas kepada siapa diwakafkannya maka wakaf itu tidak sah ${ }^{25}$.

Menurut Zuhaili26, wakaf menjadi terikat dengan keinginan sepihak yang diwujudkan dalam bentuk ijab dengan empat persyaratan, yaitu, sighat harus mengarah langsung ke wakaf. Berdasarkan hal ini, maka menggantungkan wakaf dengan persyaratan atau hal yang akan terjadi di masa mendatang adalah tidak sah atau batal akibat adanya ketidakpastian.

Shighat harus bersifat mengikat. Wakaf yang disertai persyaratan khiyar bagi diri waqif, misalnya waqif dapat menarik kembali wakaf yang telah diikrarkan adalah tidak sah. Penyerahan hak milik untuk selamanya. Wakaf dengan pembatasan waktu adalah tidak dibenarkan, seperti persyaratan wakaf sampai satu tahun. Wakaf harus diucapkan, jika waqif orang yang mampu berbicara, maka wakaf harus diucapkan secara langsung, misalnya "Saya mewakafkan". Namun jika wakaf tidak mampu mengikrarkan wakafnya secara lisan, maka ikrar wakaf bisa dilakukan dengan tertulis atau isyarat. Oleh karena itu, hukum wakaf tanpa diucapkan padahal dia mampu untuk itu adalah tidak sah.

Berdasarkan uraian tentang rukun dan syarat wakaf di atas, Imam Syafi'i sebagaimana yang dituturkan Wahbah Zuha$\mathrm{ili}^{27}$, menyimpulkan bahwa apabila waqif mewakafkan suatu barang dalam bentuk tanggungan, makanan, wewangian; wakaf tanpa menyebutkan tempat pengalokasiannya; wakaf pada penerima wakaf yang tidak diketahui; wakaf pada dirinya, wakaf pada jalan yang diharamkan; menggantungkan wakaf dengan suatu persyaratan, atau wakaf pada orang yang tidak berwenang menerimanya, semua bentuk wakaf semacam itu hukumnya batal.

Wakaf yang semula ada dalam ranah fikih, kemudian dalam perkembangannya

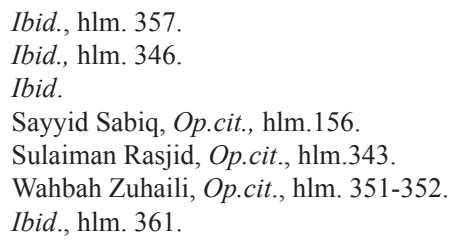


dilegislasikan atau dituangkan dalam peraturan perundang-undangan. Peraturan perundang-undangan di Indonesia yang secara khusus mengatur wakaf pada saat ini adalah Undang-Undang Nomor 41 Tahun 2004 tentang Wakaf, Peraturan Pemerintah Nomor 42 Tahun 2006 tentang Pelaksanaan Undang-Undang Nomor 41 Tahun 2004 tentang Wakaf, Peraturan Pemerintah Nomor 25 ahun 2018 tentang Perubahan Atas Peraturan Pemerintah Nomor 42 Tahun 2006 tentang Pelaksanaan Undang-Undang Nomor 41 Tahun 2004 tentang Wakaf, Peraturan Menteri Agama Nomor 73 Tahun 2013 tentang Tata Cara Perwakafan Benda Tidak Bergerak dan Benda Bergerak Selain Uang, Peraturan Menteri Agama Nomor 4 Tahun 2009 tentang Administrasi Pendaftaran Wakaf Uang, Peraturan Badan Wakaf Indonesia Nomor 1 Tahun 2008 tentang Prosedur Penyusunan Rekomendasi terhadap Permohonan Penukaran/ Perubahan Status Harta Benda Wakaf, Peraturan Badan Wakaf Indonesia Nomor 3 Tahun 2008 tentang Tata Cara Pendaftaran dan Penggantian Nazhir Harta Benda Wakaf Tidak Bergerak Berupa Tanah, dan Peraturan Badan Wakaf Indonesia Nomor 1 Tahun 2009 tentang Pedoman Pengelolaan dan Pengembangan Harta Benda Wakaf Berupa Uang.

Berdasarkan Undang-Undang Wakaf, wakaf sah apabila dilaksanakan menurut syariah $^{28}$ dan wakaf yang telah diikrarkan tidak dapat dibatalkan ${ }^{29}$. Untuk sahnya wakaf, maka harus terpenuhi unsur-unsurnya, yang meliputi enam hal ${ }^{30}$, yaitu wakif, nazhir, harta benda wakaf, ikrar wakaf, peruntukan harta benda Wakaf, dan jangka waktu wakaf. Wakif sebagai pihak yang mewakafkan harta benda miliknya dapat berupa perseorangan, organisasi, maupun badan hukum. ${ }^{31}$ Untuk wakif perseorangan disyaratkan telah dewasa, berakal sehat, tidak terhalang melakukan perbuatan hukum, dan merupakan pemilik sah atas harta benda wakaf. ${ }^{32}$ Adapun untuk wakiforganisasi hanya dapat melakukan wakaf apabila memenuhi ketentuan organisasi untuk mewakafkan harta benda wakaf milik organisasi tersebut sesuai dengan anggaran dasar organisasi yang bersangkutan ${ }^{33}$, sedangkan untuk badan hukum apabila akan mewakafkan harta bendanya disyaratkan harus memenuhi ketentuan badan hukum untuk mewakafkan harta benda wakaf milik badan hukum tersebut sesuai dengan anggaran dasar badan hukum yang bersangkutan. ${ }^{34}$

Nazhir sebagai pihak yang menerima harta benda wakaf dari wakif untuk dikelola dan dikembangkan sesuai dengan peruntukannya ${ }^{35}$ dapat berupa Perseorangan, Organisasi, atau Badan Hukum. ${ }^{36}$ Persyaratan bagi nazhir perseorangan adalah Warga Negara Indonesia, beragama Islam, dewasa, amanah, mampu secara jasmani dan rohani, dan tidak terhalang untuk melakukan perbuatan hukum. ${ }^{37}$ Untuk nazhir organisasi, persyaratan yang harus dipenuhi adalah Pengurus organisasi yang bersangkutan memenuhi persyaratan nazhir

\footnotetext{
28 Pasal 2 Undang-Undang Nomor 41 Tahun 2004 tentang Wakaf (Lembaran Negara Republik Indonesia Tahun 2004 Nomor 159, Tambahan Lembaran Negara Nomor Republik Indonesia 4459).

Ibid.. Pasal 3.

Ibid.. Pasal 6.

Undang-Undang Nomor 41 Tahun 2004 tentang Wakaf, Op. cit., Pasal 7.

Ibid.. Pasal 8 ayat (1).

Ibid.. Pasal 8 ayat (2).

Ibid.. Pasal 8 ayat (3).

Ibid.. Pasal 1 ayat (4).

Ibid.. Pasal 9.

Ibid.. Pasal 10 ayat (1).
} 
perseorangan sebagaimana disebutkan di atas; dan Organisasi tersebut bergerak di bidang sosial, pendidikan, kemasyarakatan dan/atau keagamaan Islam. ${ }^{38}$ Adapun untuk nazhir badan hukum disyaratkan bahwa Pengurus badan hukum yang bersangkutan memenuhi persyaratan nazhir perseorangan; merupakan badan hukum Indonesia yang dibentuk sesuai dengan peraturan perundangundangan yang berlaku; dan badan hukum yang bersangkutan bergerak di bidang sosial, pendidikan, kemasyarakatan, dan/ atau keagamaan Islam. ${ }^{39}$ Apabila Nazhir perseorangan, nazhir organisasi maupun nazhir badan hukum dalam jangka waktu 1 (satu) tahun sejak Akta Ikrar Wakaf (AIW) dibuat tidak melaksanakan tugasnya, maka Kepala Kantor Urusan Agama (KUA) baik atas inisiatif sendiri maupun atas usul Wakif atau ahli warisnya berhak mengusulkan kepada Badan wakaf Indonesia (BWI) untuk pemberhentian dan penggantian Nazhir. ${ }^{40}$

Masa bakti Nazhir adalah 5 (lima) tahun dan dapat diangkat kembali. Pengangkatan kembali Nazhir tersebut dilakukan oleh Badan Wakaf Indonesia (BWI) apabila yang bersangkutan telah melaksanakan tugasnya dengan baik dalam periode sebelumnya sesuai ketentuan prinsip syariah dan peraturan perundang-undangan. ${ }^{41}$ Nazhir yang telah ditunjuk bertugas melakukan pengadministrasian harta benda wakaf; mengelola dan mengembangkan harta benda wakaf sesuai dengan tujuan, fungsi, dan peruntukannya; mengawasi dan melindungi harta benda wakaf; serta melaporkan pelaksanaan tugasnya kepada Badan Wakaf Indonesia. ${ }^{42}$ Dalam melaksanakan tugasnya, Nazhir dapat menerima imbalan dari hasil bersih atas pengelolaan dan pengembangan harta benda wakaf yang besarnya tidak melebihi $10 \%$ (sepuluh persen). ${ }^{43}$

Untuk harta benda wakaf, berdasarkan Undang-Undang Wakaf, disyaratkan memiliki daya tahan lama dan/atau manfaat jangka panjang serta mempunyai nilai ekonomi menurut syariah yang diwakafkan oleh wakif. Harta benda wakaf hanya dapat diwakafkan apabila dimiliki dan dikuasasi oleh wakif secara sah. ${ }^{44}$ Harta benda wakaf terdiri dari benda tidak bergerak dan benda bergerak. Benda tidak bergerak yang dapat diwakafkan dapat berupa hak atas tanah sesuai dengan ketentuan perudang-undangan yang berlaku, baik yang sudah terdaftar maupun belum terdaftar; bangunan atau bagian bangunan yang berdiri di atas tanah; tanaman dan benda lain yang berkaitan dengan tanah; Hak milik atas satuan rumah susun sesuai dengan ketentuan peraturan perundang-undangan yang berlaku; serta benda tidak bergerak lain sesuai dengan ketentuan syariah dan peraturan perundangundangan yang berlaku. ${ }^{45}$ Adapun benda bergerak yang dapat diwakafkan meliputi logam mulia; surat berharga; kendaraan; hak atas kekayaan intelektual; hak sewa, dan benda bergerak lain sesuai dengan ketentuan syariah dan peraturan perundang-undangan yang berlaku. ${ }^{46}$

Selain benda bergerak sebagaimana disebutkan di atas, uang pun dapat diwakafkan

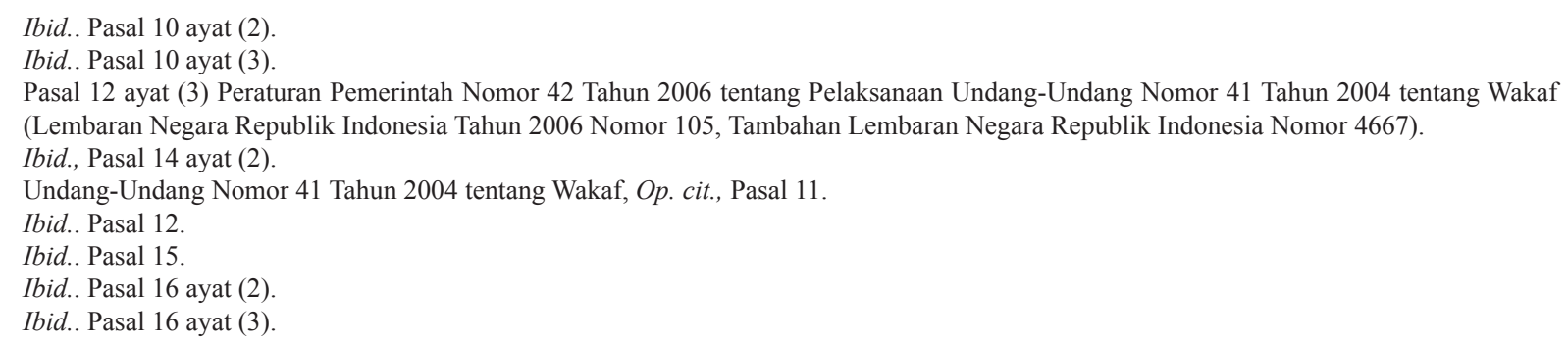


sesuai undang-undang wakaf yang berlaku saat ini. Uang yang dapat diwakafkan adalah mata uang rupiah. Dalam hal uang yang akan diwakafkan masih dalam mata uang asing, maka harus dikonversi terlebih dahulu ke dalam rupiah. ${ }^{47}$ Wakif dapat mewakafkan uangnya melalui lembaga keuangan syariah yang ditunjuk oleh menteri agama. ${ }^{48}$

Ikrar Wakaf sebagai pernyataan kehendak wakif yang diucapkan secara lisan dan/ atau tulisan kepada nazhir untuk mewakafkan harta benda miliknya harus dilakukan oleh wakif kepada nazhir di hadapan Pejabat Pembuat Akta Ikar Wakaf (PPAIW) dengan disaksikan oleh 2 (dua) orang saksi. ${ }^{49}$ Dalam hal wakif tidak dapat menyatakan ikrar wakaf secara lisan atau tidak dapat hadir dalam pelaksanaan ikrar wakaf karena alasan yang dibenarkan hukum, wakif dapat menunjuk kuasanya dengan surat kuasa yang diperkuat oleh 2 (dua) orang saksi. ${ }^{50}$

Berdasarkan ketentuan undangundang wakaf, terkait dengan peruntukan harta benda wakaf, maka dalam rangka mencapai tujuan dan fungsi wakaf, harta benda wakaf hanya dapat dipergunakan untuk sarana dan kegiatan ibadah; sarana dan kegiatan pendidikan serta kesehatan; bantuan kepada fakir miskin, anak terlantar, yatim piatu, beasiswa; untuk kemajuan dan peningkatan ekonomi umat, dan/atau untuk kemajuan kesejahteraan umum lainnya yang tidak bertentangan dengan syariah dan peraturan perundang-undangan..$^{51}$ Penetapan peruntukan harta benda wakaf tersebut dilakukan oleh wakif pada saat pelaksanaan ikrar wakaf. Dalam hal wakif tidak menetapkan peruntukan harta benda wakaf tersebut, Nazhir dapat menetapkan peruntukan harta benda wakaf yang dilakukan sesuai dengan tujuan dan fungsi wakaf. ${ }^{52}$

Pembaharuan ketentuan wakaf dalam perundang-undangan, selain menyangkut unsur dan syarat wakaf sebagaimana dipaparkan di atas, juga mengenai perubahan status harta benda wakaf. Berdasarkan Undang-Undang Wakaf, harta benda wakaf tidak boleh dijual, diwariskan, ditukar, atau dialihkan dalam bentuk pengalihan hak lainnya. ${ }^{53}$ Namun ketentuan ini bisa dikecualikan, yaitu dalam hal harta benda wakafyang telah diwakafkan digunakan untuk kepentingan umum sesuai dengan rencana umum tata ruang (RUTR) berdasarkan ketentuan peraturan perundang-undangan yang berlaku dan tidak bertentangan dengan syariah. ${ }^{54}$ Selain itu, pembaharuan di bidang perwakafan juga terlihat dalam ketentuan yang menyangkut perubahan peruntukan harta benda wakaf. Berdasarkan UndangUndang Wakaf, dalam mengelola dan mengembangkan harta benda wakaf, Nazhir dilarang melakukan perubahan peruntukan harta benda wakaf kecuali atas dasar izin tertulis dari Badan Wakaf Indonesia. Izin tersebut dapat diberikan apabila harta benda wakaf ternyata tidak dapat dipergunakan sesuai dengan peruntukan yang dinyatakan dalam ikrar wakaf. ${ }^{55}$ Hal ini berbeda dengan ajaran fikih Asy-Syafi'i, yang tidak membolehkan penukaran atau perubahan peruntukan harta benda wakaf dengan alasan

\footnotetext{
Peraturan Pemerintah Nomor 42 Tahun 2006 tentang Pelaksanaan Undang-Undang Nomor 41 Tahun 2004 tentang Wakaf, Op.cit., Pasal 22 ayat (2). 
apapun. ${ }^{56}$

Dalam pemikiran hukum Islam terkait perubahan sosial, muncul dua teori, pertama, teori keabadian atau yang disebut Teori Nomativitas Hukum Islam yang meyakini bahwa hukum Islam tidak mungkin bisa berubah dan dirubah sehingga tidak bisa beradaptasi dengan perkembangan zaman. Kedua, teori adaptabilitas hukum Islam yang meyakini bahwa hukum Islam sebagai hukum yang diciptakan Tuhan untuk kepentingan manusia dapat beradaptasi dengan perkembangan zaman sehingga ia bisa dirubah untuk mewujudkan kemaslahatan bagi manusia. Kerangka dasar pemikiran yang melatarbelakangi teori adaptabilitas adalah prinsip maslahah yang merupakan tujuan hukum Islam itu sendiri. ${ }^{57}$

Dalam persoalan wakaf, fikih wakaf yang dikemukakan oleh para ulama sebagaimana diuraikan di atas tidak terlepas dari konteks ruang dan waktu ketika fikih tersebut diajarkan, sehingga seiring dengan perubahan waktu dan tempat maka apa yang diajarkan para fuqaha di atas ada beberapa hal yang kurang sesuai dengan kondisi sekarang. Oleh karena itu, terhadap apa yang diajarkan para fuqaha di atas terbuka kemungkinan untuk dilakukan pembaharuan. Dalam upaya melakukan pembaharuan fikih tersebut, prinsip kemaslahatan dan al-maqasid assyariah menjadi pedoman utama.

Jika dicermati lebih jauh, ditemukan tiga hal terkait pengaturan wakaf dari ajaran fikih ke dalam peraturan perundang-undangan di Indonesia. Pertama, ketentuan wakaf dalam peraturan perundang-undangan yang berbeda dengan ketentuan yang ada dalam ajaran fikih; Kedua, ketentuan wakaf dalam peraturan perundang-undangan yang bersifat perincian dari apa yang sudah dikemukakan dalam ajaran fikih; dan Ketiga, ketentuan wakaf dalam peraturan perundang-undangan yang sama sekali baru, dalam arti bahwa hal tersebut belum diatur dalam ajaran fikih. Hal tersebut akan dijabarkan lebih lanjut dalam uraian di bawah ini.

Pertama, ketentuan wakaf dalam perundang-undangan yang berbeda dengan apa yang diajarkan dalam fikih wakaf. Jika dicermati secara mendalam, perbedaan tersebut nampak jelas pada rukun atau unsur wakaf dan syarat-syaratnya. Dalam ajaran fikih, disebutkan bahwa rukun wakaf ada empat, yaitu waqif, mauquf, mauquf 'alaih, dan shighat. ${ }^{58}$ Adapun dalam UndangUndang Wakaf disebutkan bahwa unsur wakaf ada enam, yaitu di samping keempat unsur sebagaimana diajarkan dalam fikih di atas, masih ada dua unsur lagi, yaitu nazhir dan jangka waktu wakaf ${ }^{59}$. Selanjutnya untuk wakif dan nazhir, dalam UndangUndang Wakaf cakupannya diperluas, yaitu tidak hanya perseorangan, melainkan juga mencakup organisasi dan badan hukum. ${ }^{60}$ Untuk benda yang bisa diwakafkan, dalam Undang-Undang Wakaf cakupannya juga diperluas, yaitu disamping benda-benda yang disebutkan dalam fikih, juga mencakup uang dan surat-surat berharga. ${ }^{61}$ Syarat-syarat dari masing-masing rukun atau unsur wakaf di atas, dalam Undang-Undang Wakaf diatur lebih rinci dari pada yang ada dalam ajaran fikih, seperti syarat untuk wakif, nazhir

\footnotetext{
56 Departemen Agama RI, 2008, Panduan Pemberdayaan Tanah Wakaf Produktif Strategis di Indonesia, Direktorat Pemberdayaan Wakaf Direktorat Jenderal Bimbingan Masyarakat Islam, Jakarta, hlm. 67.

57 Miftahul Amri, "Konsep Maslahat Dalam Penetapan Hukum Islam (Telaah Kritis Pemikiran Hukum Islam Najamuddin At- ThuFi)", EtTijarie, Vol. 5, No. 2, 2018.

Sulaiman Rasjid, op.cit, hlm. 341-342, Wahbah Zuhaili, Op.cit., hlm. 343

Undang-Undang Nomr 41 Tahun 2004 tentang Wakaf, Op. cit., Pasal 6.

Ibid., Pasal 7 dan 9.

Ibid., Pasal 16 ayat (3)
} 
maupun harta yang bisa diwakafkan.

Dalam ajaran fikih, wakif disyaratkan:

a) Berhak berbuat kebaikan, sekalipun ia bukan Islam, b). Kehendak sendiri, tidak sah karena dipaksa ${ }^{62}$, c) baligh dan berakal. ${ }^{63}$ Dalam ketentuan perundangundangan, syarat untuk wakif (khususnya wakif perseorangan) diatur lebih konkrit, yaitu dewasa, berakal sehat, tidak terhalang melakukan perbuatan hukum, dan pemilik sah harta benda wakaf. ${ }^{64}$

Selanjutnya untuk nazhir, dalam ajaran fikih, nazhir disyaratkan pertama, harus adil (menjalankan tuntunan agama dengan konsekuen, baik perintah maupun larangan), kedua, memiliki kemampuan (kuat dan mampu mengatur sesuatu yang menjadi kewajibannya sebagai nazhir), dan ketiga, memperoleh petunjuk untuk melakukan pengelolaan. ${ }^{65}$ Adapun dalam perundangundangan wakaf, persyaratan untuk nazhir (khususnya nazhir perseorangan) diatur lebih rinci, yaitu warga negara Indonesia, beragama Islam, dewasa, amanah, mampu secara jasmani dan rohani, dan tidak terhalang untuk melakukan perbuatan hukum. ${ }^{66}$

Adapun untuk benda yang diwakafkan, dalam ajaran fikih dinyatakan bahwa syarat benda yang diwakafkan adalah: a) Kekal zatnya, berarti bila manfaatnya diambil, zat barang itu tidak rusak; dan b) Kepunyaan yang mewakafkan. ${ }^{67}$ Fuqaha lainnya menyatakan bahwa syarat suatu benda dapat diwakafkan adalah: a) Mauquf harus berupa barang yang telah tersedia yang dapat dimanfaatkan serta wujudnya tetap utuh selama-lamanya; b)
Mauquf harus berupa barang yang sudah berwujud; c) Mauquf harus berupa kekayaan yang berharga, mubah, sudah diketahui, serta dapat dimiliki secara penuh. ${ }^{68}$ Selanjutnya menurut pendapat yang shahih, wakaf berupa barang berharga (emas dan perak) atau uang dinar dan dirham tidak diperbolehkan karena barang berharga semacam itu tidak boleh disewakan. ${ }^{69}$ Dalam perundang-undangan wakaf ditentukan bahwa syarat suatu benda dapat diwakafkan adalah memiliki daya tahan lama dan/atau manfaat jangka panjang, mempunyai nilai ekonomi menurut syariah, serta dimiliki dan dikuasasi oleh wakif secara sah. ${ }^{70}$ Uang termasuk salah satu harta yang bisa diwakafkan menurut perUndangUndang an wakaf. ${ }^{71}$

Untuk unsur peruntukan harta benda wakaf, dalam Undang-Undang Wakaf hal tersebut juga diatur lebih rinci, yang intinya lebih berorientasi pada kepentingan umum (wakaf khairi) dan bukan untuk kepentingan individu tertentu (wakaf ahli). Peruntukan harta benda wakaf tersebut mencakup: a) Sarana dan kegiatan ibadah; b) Sarana dan kegiatan pendidikan serta kesehatan; c) Bantuan kepada fakir miskin, anak terlantar, yatim piatu, beasiswa; d) Kemajuan dan peningkatan ekonomi umat, dan/atau e) Kemajuan kesejahteraan umum lainnya yang tidak bertentangan dengan syariah dan peraturan perundang-undangan. ${ }^{72}$

Dengan melihat pembahaharuan di atas, maka siapa yang bisa berwakaf dan apa yang bisa diwakafkan cakupannya semakin luas. Dengan adanya ketentuan seperti

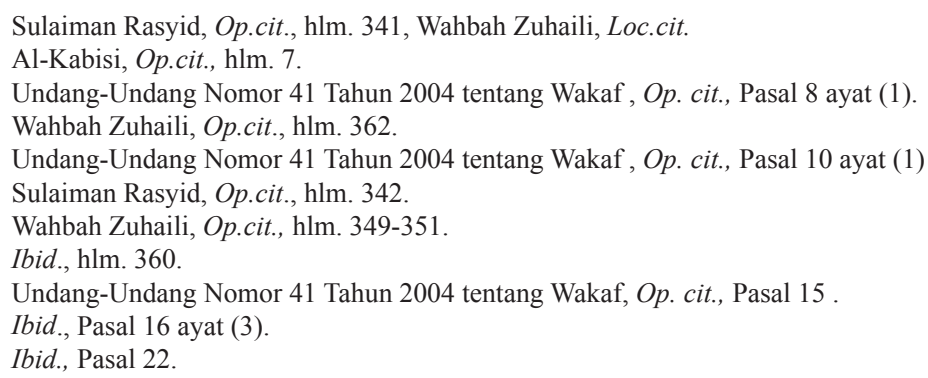


ini maka akan memperluas kesempatan bagi berbagai pihak untuk berwakaf sehingga peran wakaf untuk meningkatkan kesejahteraan umat akan dapat terwujud. Hal itu akan mendukung terealisasinya tujuan hukum Islam yang terangkum dalam al-maqashid as-syariah, yaitu memelihara agama, jiwa, akal, keturunan, dan harta. ${ }^{73}$

Di samping hal-hal yang telah disebutkan di atas, unsur yang tidak ada dalam fikih wakaf namun ada dalam perundang-undangan wakaf adalah mengenai jangka waktu wakaf. Dalam ajaran fikih, khususnya dari madzab Syafi'i, wakaf adalah untuk selamanya ${ }^{74}$, sehingga hak kepemilikan atas harta yang diwakafkan tersebut terlepas dari wakif dan wakif tidak punya hak untuk menarik kembali atas harta yang diwakafkannya. Hal ini berbeda dengan ketentuan dalam Undang-Undang Wakaf yang memungkinkan jangka waktu wakaf tidak harus selamanya, tetapi juga dapat untuk sementara waktu. ${ }^{75}$ Hal ini memungkinkan seseorang yang memiliki sejumlah harta tertentu, misalnya sejumlah uang, untuk mewakafkan uangnya dalam jangka waktu tertentu, misalnya 20 (dua puluh tahun), sehingga di satu sisi, pihak lain bisa mengambil manfaat atas uang tersebut, dan di sisi lain, si wakif masih tetap bisa memiliki uangnya kembali setelah jangka waktu wakaf habis.

Kedua, ketentuan dalam perundangundangan Wakaf yang lebih bersifat pengembangan dan perincian dari apa yang telah ada dalam ajaran fikih. Ketentuan tersebut adalah mengenai perubahan status dan peruntukan harta benda wakaf.
Dalam ajaran fikih, dimungkinkan adanya perubahan status kepemilikan atau perubahan penggunaan atas harta yang diwakafkan, misalnya karena terjadinya perubahan keadaan yang mengakibatkan harta wakaf tidak bisa dipergunakan sesuai ikrar wakaf semula. ${ }^{76}$ Dalam hal ini, harta wakaf boleh dijual dan diganti dengan harta lain yang bisa mendatangkan manfaat bagi mauquf 'alaih. Namun demikian dalam ajaran fikih tidak dijelaskan secara rinci mengenai alasanalasan yang membolehkan adanya perubahan status harta wakaf, prosedur untuk melakukan perubahan status kepemilikan dan peruntukan harta wakaf, serta mengenai persyaratan harta benda lain sebagai pengganti atau penukar atas harta wakaf semula. Dalam Undang-Undang Wakaf, perubahan status maupun peruntukan harta benda wakaf diatur sedemikian rinci, mulai dari alasan-alasan yang memungkinkan perubahan status harta benda wakaf, prosedur perubahan status, sampai menyangkut syarat harta benda pengganti atas harta benda wakaf semula. ${ }^{77}$ Hal ini semua adalah untuk memberikan kepastian hukum bagi pihak-pihak terkait dan menghindari adanya kesimpangsiuran maupun penyimpangan dalam masalah perubahan status dan peruntukan harta wakaf.

Pengelolaan dan pengembangan harta benda wakaf. Dalam ajaran fikih, urusan pengelolaan dan pengembangan harta wakaf hanya diatur secara garis besar. Ajaran fikih hanya menggariskan bahwa dalam pengelolaan dan pengembangan harta wakaf harus mengikuti syarat-syarat yang telah ditentukan oleh wakif ${ }^{78}$. Dalam UndangUndang Wakaf, persoalan pengelolaan dan

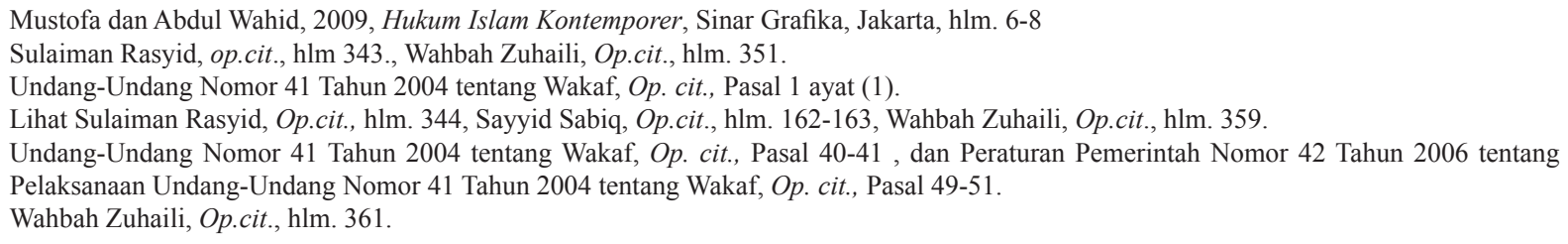


pengembangan harta benda wakaf diatur sedemikian rinci, mulai dari syarat-syarat yang harus dipenuhi oleh pihak yang bertugas mengelola harta benda wakaf (nazhir), kewajiban dan hak bagi pengelola wakaf (nazhir), sampai masalah rambu-rambu yang harus dipatuhi nazhir dalam pengelolaan harta benda wakaf ${ }^{79}$.

Ketiga, ketentuan wakaf dalam perundang-undangan yang sama sekali baru, dalam arti bahwa ketentuan tersebut belum terdapat dalam ajaran fikih. Ketentuan tersebut adalah menyangkut pendaftaran dan pengumuman harta benda wakaf. ${ }^{80}$ Dalam Undang-Undang Wakaf dinyatakan bahwa Pejabat Pembuat Akta Ikrar Wakaf (PPAIW) atas nama nazhir wajib mendaftarkan harta benda wakaf ke instansi yang berwenang. Dengan telah dilakukannya pendaftaran tersebut, Badan Wakaf Indonesia dan Menteri Agama selanjutnya akan mengumumkan harta benda wakaf yang telah terdaftar kepada masyarakat. Hal ini akan memberikan kepastian atas harta wakaf tersebut sehingga dapat diminimalisir terjadinya peralihan atau pemindahtanganan harta benda wakaf kepada pihak lain secara tidak sah. Dengan demikian, hal ini akan melindungi harta wakaf itu sendiri. Kelembagaan Badan Wakaf Indonesia (BWI) ${ }^{81}$ Dalam UndangUndang Wakaf dinyatakan bahwa Badan Wakaf Indonesia adalah lembaga independen untuk mengembangkan perwakafan di Indonesia. Badan Wakaf Indonesia (BWI) berkedudukan di ibu kota negara dan dapat membentuk perwakilannya di Provinsi atau Kabupaten sesuai dengan kebutuhan. BWI dibentuk dengan tugas dan wewenang untuk:
1) Melakukan pembinaan terhadap nazhir dalam mengelola dan mengembangkan harta benda wakaf; 2) Melakukan pengelolaan dan pengembangan harta benda wakaf berskala nasional dan internasional; 3) Memberikan persetujuan dan/atau izin atas perubahan peruntukan dan status harta benda wakaf; 4) Memberhentikan dan mengganti nazhir; 5) Memberikan persetujuan atas penukaran harta benda wakaf; 6) Memberikan saran dan pertimbangan kepada Pemerintah dalam membuat kebijakan di bidang perwakafan. ${ }^{82}$

Prosedur atau tata cara berwakaf. ${ }^{83}$ Prosedur atau tata cara berwakaf dalam fikih tidak banyak diatur, dalam ajaran fikih hanya dinyatakan bahwa wakif yang akan mewakafkan hartanya diharuskan mengikrarkan wakafnya secara tegas atas hartanya tersebut untuk jangka waktu tidak terbatas dan tanpa adanya hak khiyar. Hal ini berbeda dengan ketentuan Undang-Undang Wakaf yang mengatur secara rinci tata cara perwakafan, mulai dari syarat-syarat yang harus dipenuhi dan dokumen yang harus diserahkan oleh wakif, pengucapan ikrar wakaf, sampai terbitnya bukti telah terjadinya wakaf (akta/sertifikat).

Dengan memperhatikan uraian di atas, maka terlihat bahwa ketentuan-ketentuan yang ada dalam Undang-Undang Wakaf sebagian besar mengadopsi ketentuanketentuan yang ada dalam ajaran fikih namun dengan beberapa penyesuaian. Penyesuaian tersebut dilakukan untuk mengakomodasi perkembangan yang ada saat ini. Beberapa penyesuaian tersebut berorientasi pada tujuan untuk mewujudkan kemaslahatan sebagaimana digariskan dalam hukum Islam.

\footnotetext{
Peraturan Pemerintah Nomor 42 Tahun 2006 tentang Pelaksanaan Undang-Undang Nomor 41 Tahun 2004 tentang Wakaf, Op. cit., Pasal $42-$ 45, dan Pasal 45-48.

Ibid., Pasal 32-38 dan Pasal 38-44.

Undang-Undang Nomor 41 Tahun 2004 tentang Wakaf, Op. cit., Pasal 47-61.

Ibid., Pasal 49.

Ibid., Pasal 17-21.
} 
Mewujudkan Maslahah merupakan tujuan utama hukum Islam (Syari'ah). Dalam setiap aturan hukumnya, hukum Islam menjadikan maslahah sebagai acuan sehingga lahir kebaikan/kemanfaatan dan terhindarkan keburukan/kerusakan, yang pada gilirannya terealisasinya kemakmuran dan kesejahteraan di muka bumi. Dari aspek substantif, adanya perluasan cakupan pihak yang bisa menjadi wakif, nazhir, dan harta yang dapat diwakafkan akan membuka kesempatan yang lebih luas untuk dilakukannya wakaf. Dari aspek administratif, adanya pengaturan yang jelas dan terperinci dalam proses perwakafan, mulai dari ikrar wakaf, pendaftaran harta benda wakaf, pengelolaan wakaf, sampai persoalan perubahan status dan peruntukan harta benda wakaf, akan memberikan kepastian dan kemaslahatan dalam perwakafan.

\section{Prinsip-prinsip yang Dapat Ditarik dari Pengaturan Fikih Wakaf ke Dalam Peraturan Perundang-undangan di Indo- nesia}

Berdasarkan uraian yang telah dipaparkan di atas, dapat ditarik beberapa prinsip dari pengaturan fikih wakafke dalam peraturan perundang-undangan dengan beberapa penyesuaian sebagaimana dibahas sebelumnya. Beberapa prinsip tersebut adalah sebagai berikut:

a. Prinsip Kemaslahatan atau kemanfaatan

Mewujudkan kemaslahatan bagi manusia, baik secara individual maupun sosial, jasmani maupun rohani, dari dunia sampai akhirat merupakan tujuan pokok hukum Islam. Kemaslahatan sebagai tujuan pokok hukum Islam tersebut kemudian diperinci menjadi lima hal, yaitu memelihara agama, memelihara jiwa, memelihara akal, memelihara keturunan, dan memelihara harta. Pengertian maslahah menurut alSyatibi adalah: ${ }^{84}$

"that which concerns the subsistence of human life, the completion of man's lifelihood, and the acquisition of what his emotional and intellectual qualities require of him, in an absolute sense".

Ketentuan dalam perundangan wakaf yang mengadopsi ajaran fikih wakaf dengan beberapa penyesuaian sebagaimana diuraikan di atas telah mencerminkan prinsip kemaslahatan. Hal ini nampak dari ketentuan yang memperluas cakupan pihak yang bisa menjadi wakif, harta benda yang bisa diwakafkan, dan pihak yang bisa menjadi nazhir. Dengan perluasan cakupan ini, akan mengoptimalkan peran dan fungsi wakaf baik untuk kepentingan ibadah maupun peningkatan kesejahteraan umum.

b. Prinsip Kepastian Hukum

Menurut Utrecht, kepastian hukum mengandung dua pengertian, yaitu pertama, adanya aturan yang bersifat umum yang membuat individu mengetahui perbuatan apa yang boleh atau tidak boleh dilakukan, dan kedua, berupa keamanan hukum bagi individu dari kesewenangan pemerintah karena dengan adanya aturan yang bersifat umum itu individu dapat mengetahui apa saja yang boleh dibebankan atau dilakukan oleh Negara terhadap individu ${ }^{85}$

Adanya kepastian hukum berdampak positif bagi masyarakat karena masyarakat akan mengetahui secara jelas mengenai hak dan kewajiban menurut hukum. Tanpa ada kepastian hukum maka orang tidak tahu apa yang harus diperbuat, tidak mengetahui perbuatanya benar atau salah, dilarang atau tidak dilarang oleh hukum. Kepastian hukum ini dapat diwujudkan melalui penormaan

84 Muhammad Khalid Masud, Islamic Legal Philosophy, sebagaimana dikutip Jazuni, Op.cit., hlm. 180-181.

85 Riduan Syahrani, 1999, Rangkuman Intisari Ilmu Hukum, Penerbit Citra Aditya Bakti,Bandung, hlm.23. 
yang baik dan jelas dalam suatu UndangUndang .

Penormaan yang jelas akan berimplikasi pada kejelasan penerapanya. Prinsip kepastian hukum menghendaki pengaturan yang seragam untuk suatu perbuatan tertentu. Pengaturan wakaf sebelum adanya Undang-Undang Wakaf masih tersebar dalam beberapa peraturan dan belum mengatur wakaf secara lengkap. Dengan terjadinya perkembangan yang cukup pesat mengakibatkan ada beberapa hal yang belum mendapat pengaturan yang memadai, misalnya persoalan wakaf uang, hak dan kewajiban nazhir, alokasi peruntukan wakaf, perubahan peruntukan dan status harta benda wakaf, dan sebagainya. Hal-hal tersebut perlu mendapat pengaturan yang pasti untuk menghindari kesimpangsiuran dalam praktik wakaf. Terhadap persoalan tersebut, UndangUndang Wakaf telah mengaturnya dengan ketentuan yang jelas dan pasti, sehingga hal ini mendorong terwujudnya kepastian hukum di bidang perwakafan.

c. Prinsip Profesionalitas

Profesionalitas adalah sikap para anggota profesi yang benar-benar menguasai dan sungguh-sungguh kepada profesinya. Profesionalitas adalah suatu sebutan terhadap kualitas sikap para anggota profesi pada profesinya serta derajat pengetahuan dan keahlian yang mereka miliki untuk dapat melakukan tugas mereka. Dengan kata lain, profesional adalah seorang yang memiliki kompetensi dalam suatu pekerjaan tertentu. ${ }^{86}$ Dengan demikian, profesionalitas lebih menggambarkan suatu "keadaan" derajat keprofesian seseorang dilihat dari sikap, pengetahuan, dan keahlian yang diperlukan untuk melaksanakan tugasnya ${ }^{87}$ Profesionalitas menghendaki penyelesaian atau pengerjaan suatu hal dengan keahlian tertentu sesuai standar. Profesional adalah bersangkutan dengan profesi, memerlukan kepandaian khusus untuk menjalankannya. ${ }^{88}$ Dalam Undang-Undang Wakaf, profesionalitas tercermin dari ketentuan yang mengatur syarat-syarat yang harus dipenuhi nazhir, baik untuk nazhir perseorangan, nazhir organisasi, maupun nazhir badan hukum. Salah satu syarat bagi nazhir adalah "memiliki kemampuan secara jasmani maupun rohani" untuk mengelola wakaf. ${ }^{89}$ Dengan persyaratan seperti ini berimplikasi bahwa tidak setiap orang dapat menjadi nazhir wakaf. Hanya orang-orang yang memiliki kapabilitas saja yang dapat menjadi nazhir wakaf. Profesionalitas sangat penting untuk mewujudkan tujuan wakaf itu sendiri, yaitu mengoptimalkan pemanfaatan harta benda wakaf sesuai dengan fungsinya.

d. Prinsip Akuntabilitas

Akuntabilitas adalah suatu prinsip bahwa setiap kegiatan dan hasil akhir dari kegiatan harus dapat dipertanggungjawabkan sesuai dengan ketentuan peraturan perundang-undangan yang berlaku. Dengan kata lain, akuntabilitas adalah suatu keadaan, pekerjaan, tugas dan tindakan yang dapat dipertanggungjawabkan baik secara hukum maupun secara moral. ${ }^{90}$ Akuntabilitas dapat diukur dari sejumlah dimensi, di antaranya: transparansi, pertanggungjawaban, pengendalian, tanggung jawab, dan responsivitas. ${ }^{91}$

86 Kusnanto,"Pengertian Profesional", https://www.pelajaran.co.id/2017/14/pengertian-profesi-profesional-profesionalisme-profesionalitasdan-profesionalisasi-menurut-para-ahli.html, diakses tanggal 11 Maret 2020

87 Syamsul Hadi "Pengertian Profesionalitas", https://www.maribelajarbk.web.id/2015/04/pengertian-profesional-profesi.html, diakses tanggal 19 Oktober 2017.

88 Tim Penyusun Kamus Pusat Pembinaan dan Pengembangan Bahasa Departemen Pendidikan dan Kebudayaan, 1989, Kamus Besar Bahasa Indonesia, Cet.ke-2, Balai Pustaka, Jakarta, hlm. 702

89 Undang-Undang Nomor 41 Tahun 2004 tentang Wakaf, Op. cit., Pasal 10 ayat (1)

90 Akuntabilitas", https://www.kamusbesar.com/akuntabilitas, diakses tanggal 19 Oktober 2017. 
Dalam Undang-Undang Wakaf, prinsip akuntabilitas tersebut sangat dijunjung tinggi. Hal ini nampak pada ketentuan yang mewajibkan nazhir untuk melaporkan aktivitas pengelolaan wakaf yang telah dilakukannya kepada Badan Wakaf Indonesia $(\mathrm{BWI})^{92}$ dan ketentuan yang memungkinkan untuk memberhentikan nazhir dari jabatannya jika yang bersangkutan tidak melaksanakan kewajibannya dengan baik. Prinsip akuntabilitas juga diterapkan dalam persoalan perubahan peruntukan dan status harta benda wakaf. Dalam persoalan ini harus jelas alasan dilakukannya perubahan peruntukan dan status harta benda wakaf, prosedur perubahan yang harus ditempuh, serta penggantian harta benda wakaf tersebut dengan harta benda lain yang senilai. ${ }^{93}$

\section{Kesimpulan}

Adaptabilitas pengaturan fikih wakaf ke dalam legislasi nasional ditunjukan oleh beberapa hal sebagai berikut: unsur-unsur wakaf (wakif, nazhir, harta benda wakaf, ikrar wakaf, peruntukan wakaf, dan jangka waktu wakaf), pengelolaan dan pengembangan harta benda wakaf, pendaftaran dan pelaporan harta benda wakaf, serta perubahan peruntukan dan status harta benda wakaf. Penyesuaian atau pembaharuan terkait pihak yang bisa berwakaf, harta benda yang bisa diwakafkan, dan jangka waktu wakaf, akan memperluas kesempatan berbagai pihak untuk berwakaf sehingga peran wakaf untuk meningkatkan kesejahteraan sosial ekonomi umat akan terwujud.

Prinsip-prinsip yang dapat ditarik dari pengaturan fikih wakaf ke dalam peraturan perundang-undangan, yakni: pertama, prinsip kemaslahatan, kedua, prinsip kepastian hukum, ketiga, prinsip profesionalitas, dan keempat, prinsip akuntabilitas.

\section{DAFTAR PUSTAKA}

A. Buku

Afif, dan Wahab, Abdul, 1991, Fiqh (Hukum Islam) antara Pemikiran Teoritis dengan Praktis, Fakultas Syariah IAIN Sunan Gunung Djati. Al-Kabisi, dan Abdulah, Muhammad, 2004, Hukum Wakaf, Kajian Kontemporer Pertama dan Terlengkap tentang Fungsi dan Pengelolaan Wakaf serta Penyelesaian Atas Sengketa Wakaf, terj. Ahrul Sani Fathurrahman, Dompet Dhuafa Republika dan IIMaN, Jakarta.

Departemen Agama RI, 2003, Perkembangan Pengelolaan Wakaf di Indonesia, Proyek Peningkatan Zakat dan Wakaf Direktorat Jenderal Bimbingan Masyarakat Islam dan Penyelenggaraan Haji, Jakarta.
, 2008, Panduan Pemberdayaan Tanah Wakaf Produktif Strategis di Indonesia, Direktorat Pemberdayaan Wakaf Direktorat Jenderal Bimbingan Masyarakat Islam, Jakarta. , 2006, Fikih Wakaf, Jakarta. , 2013, Paradigma Baru Wakaf di Indonesia, Jakarta.

Hazairin, 1990, Demokrasi Pancasila, Rineka Cipta, Jakarta.

Jazuni, 2005, Legislasi Hukum Islam di Indonesia, Citra Aditya Bakti, Bandung

Mawardi, dan Imam, Ahmad, 2010, Figh Minoritas Fiqh Al-Aqalliyat dan Evolusi Maqashid AlSyari'ah dari Konsep ke Pendekatan, LKiS, Yogyakarta.

Wicaksono, Kristian, “Akuntabilitas Organisasi Sektor Publik”, https://jurnal.ugm.ac.id/jkap/article/view/7523, diakes tanggal 19 Oktober 2017.

92 Undang-Undang Nomor 41 Tahun 2004 tentang Wakaf, Op. cit., Pasal 11.

93 Ibid., Pasal 49-51. 
Mertokusumo, Sudikno, 2007, Mengenal Hukum Suatu Pengantar, Liberty, Yogyakarta.

Miles, Matthew B, et.al., 1992, Qualitative Data Analysis (Analisis Data Kualitatif), terj. Tjetjep Rohendi Rohidi, UI-Press, Jakarta

Mu'allim, Amir dan Yusdani, 1999, Konfigurasi Pemikiran Hukum Islam, UII Press, Yogyakarta.

Mustofa dan Wahid, Abdul, 2009, Hukum Islam Kontemporer, Sinar Grafika, Jakarta.

Nasution, Harun, 1988, "Ijtihad Sumber Ketiga Ajaran Islam" dalam Haidar Baqir, Ijtihad Dalam Sorotan, Mizan, Bandung.

Rasjid, Sulaiman, 1997, Fiqh Islam, Sinar Baru Algensindo, Bandung.

Sabiq, Sayyid, 1997, Fiqih Sunnah, Jilid 14, terj. Mudzakir A.S., Cet. 9, Alma'arif, Bandung.

Shiddieqy, Ash, dan Hasbi, 1985, Pengantar Ilmu Fiqh, Bulan Bintang, Jakarta.

Shomad, Abd., 2012, Hukum Islam, Penormaan Prinsip Syariah Dalam Hukum Indonesia, Kencana Prenada Media Group, Jakarta.

Syahrani, Riduan, 1999, Rangkuman Intisari Ilmu Hukum, Citra Aditya Bakti, Bandung.

Tim Penyusun Kamus Pusat Pembinaan dan Pengembangan Bahasa Departemen Pendidikan dan Kebudayaan, 1989, Kamus Besar Bahasa Indonesia, Cet.ke-2, Balai Pustaka, Jakarta.

Zuhaili, Wahbah, 2010, Fiqih Imam Syafi'i, Mengupas Masalah Fiqhiyah Berdasarkan Al-Qur'an dan Hadits, Jilid 2, Al-Mahira, Jakarta.

\section{B. Peraturan Perundang-undangan}

Undang-Undang Nomor 41 Tahun 2004 tentang Wakaf (Lembaran Negara Republik Indonesia Tahun 2004 Nomor 159, Tambahan
Lembaran Negara Republik Indonesia Nomor 4459).

Peraturan Pemerintah Nomor 42 Tahun 2006 tentang Pelaksanaan Undang-Undang Nomor 41 Tahun 2004 tentang Wakaf (Lembaran Negara Republik Indonesia Tahun 2006 Nomor 105).

Peraturan Pemerintah Nomor 25 ahun 2018 tentang Perubahan Atas Peraturan Pemerintah Nomor 42 Tahun 2006 tentang Pelaksanaan Undang-Undang Nomor 41 Tahun 2004 tentang Wakaf (Lembaran Negara Tahun 2018 Nomor 93).

\section{Jurnal}

Miftahul, Amri, "Konsep Maslahat Dalam Penetapan Hukum Islam (Telaah Kritis Pemikiran Hukum Islam Najamuddin AtThuFi)", Et-Tijarie, Vol. 5, No. 2, Juli 2018.

\section{Internet}

"Akuntabilitas", https://www.kamusbesar. com/akuntabilitas, diakses tanggal 19 Oktober 2017.

Hadi, Syamsul, "Pengertian Profesionalitas", https://www.maribelajarbk.web.id/2015/04/ pengertian-profesional-profesi.html, diakses tanggal 19 Oktober 2017.

Kusnanto,"Pengertian Profesional", https://www. pelajaran.co.id/2017/14/pengertian-profesiprofesional-profesionalisme-profesionalitasdan-profesionalisasi-menurut-para-ahli. html, diakses tanggal 11 Maret 2020.

Wicaksono, Kristian, "Akuntabilitas Organisasi Sektor Publik", https://jurnal.ugm.ac.id/ jkap/article/view/7523, diakes tanggal 19 Oktober 2017. 